\title{
Pobreza e seletividade espacial no bairro universitário Camobi, Santa Maria, RS: uma análise à partir dos usos do território
}

\author{
Poverty and spatial selectivity in the university neighborhood of Camobi, \\ Santa Maria, RS: an analysis from the territory use
}

\section{Pedro Leonardo Cezar Spode'; Maurício Rizzatti"; Lilian Hahn Mariano da Rocha"l'; Rivaldo Mauro de FariaIV; lago Turba CostaV}

\section{RESUMO}

Os usos do território expõem as contradições históricas que se materializam no espaço e permitem a compreensão de determinados fenômenos socioespaciais, como a pobreza urbana, a privação, a seletividade e as desigualdades sociais em geral. Desse modo, o objetivo central deste estudo é pautado na análise dos usos do território urbano do Bairro Camobi, em Santa Maria, Rio Grande do Sul. Para isso, recorreu-se ao levantamento bibliográfico, a legislação urbana e trabalhos de campo. Estes foram utilizados para levantamento de dados, bem como, para construção de acervo fotográfico do Bairro em estudo. Somaram-se ao total 10 trabalhos de campo dos anos de 2016 e 2019. Camobi, em tempos atuais, apresenta-se como um Bairro heterogêneo, com diversas formas sobrepostas de uso do território, influenciados, principalmente pela Universidade Federal de Santa Maria (UFSM) e pela Base Aérea de Santa Maria (BASM). Estes determinam a dinâmica espacial do Bairro, com a reprodução de condomínios horizontais e edifícios verticais, configurados como espaços de seletividade no Bairro. O uso ferroviário, que no passado ocupou papel de destaque, hoje é caracterizado pelas rugosidades que marcam a paisagem da região Norte de Camobi, que denotam áreas de pobreza urbana e privação no Bairro.

Palavras-chave: Desigualdade Socioespacial; Pobreza Urbana; Território Usado; Rugosidades; UFSM.

\section{ABSTRACT}

The territory use exposes the historical contradictions which materialize itself in space and allow the comprehension of certain socio-spatial phenomena, like the urban poverty, the deprivation, the selectivity and the social differences in general. Thereby, the main objective of this study is ruled in the analysis of the urban territory use in the neighborhood of Camobi, in Santa Maria, Rio Grande do Sul. For this, a bibliographic survey, the urban legislation and fieldworks were executed. These

'Mestrando em Geografia pelo Programa de Pós-Graduação em Geografia (PPGGEO - UFSM) da Universidade Federal de Santa Maria Email: pedrospode@gmail.com ORCID: https://orcid.org/0000-0002-7562-5430

"Doutorando em Geografia (Passagem Direta para o Doutorado) pelo Programa de Pós-Graduação em Geografia (PPGGeo) da UFSM Email: geo.mauricio.rizzatti@gmail.com ORCID: https://orcid.org/0000-0002-1795-9002

I'Pesquisadora e coordenadora do Laboratorio de Geografia Urbana e professor Nível C2 da Universidade Federal de Santa Maria E-mail: Ihrocha@yahoo.com ORCID: https://orcid.org/0000-0001-9600-7853

IVProfessor Adjunto do Departamento de Geociências da Universidade Federal de Santa Maria E-mail: rivaldo.faria@ufsm.br ORCID: https://orcid.org/0000-0002-4005-8309

`Mestrando em Geografia pelo Programa de Pós-Graduação em Geografia (PPGGeo) da UFSM E-mail: iagoturba06@gmail.com ORCID: https://orcid.org/0000-0002-1102-9605 
were used for the data gathering, as well as, for the photographic collection creation in the studied neighborhood. The total of 10 fieldworks were gathered from the years of 2016 and 2019. Camobi, in current times, presents itself as a heterogeneous neighborhood, with many overlapped shapes of territory use, mainly influenced by the Federal University of Santa Maria (UFSM) and Air Base of Santa Maria (BASM). They determine the neighborhood spatial dynamics, with the propagation of horizontal condos and vertical buildings, configured as spatial selectivity in the neighborhood. The rail use, which in the past had a prominent role, today is characterized by the roughness which define the landscape in the North region of Camobi, these denote urban poverty areas and deprivation in the neighborhood.

Keywords: Socio-spatial Inequality; Urban Poverty; Used Territory; Roughness; UFSM.

\section{INTRODUÇÃO}

O princípio da seletividade espacial foi apresentado por Santos ([1996], 2017) como forma de explicar a racionalidade do capitalismo no meio técnico-científicoinformacional. Sabemos que a seletividade, que é um problema inscrito na natureza do capitalismo, foi amplamente discutida na teoria marxista, mas ainda não havia sido adequadamente explorada a sua dimensão espacial, sobretudo na atual fase da reprodução do capital. Ainda na década de 1970 o autor apresentou o conceito de formação socioespacial, introduzindo à teoria da formação social de Marx, a sua dimensão geográfica. A formação socioespacial foi assim apresentada como uma superestrutura produzida pelas relações sociais e históricas, mas só compreensiva na realidade geográfica do presente. Dessa forma, na formação socioespacial está não apenas a dialética do tempo, mas também a dialética do espaço. A formação socioespacial se apresenta, então, como uma totalidade expressa pela própria dialética das formas-conteúdo ou objetos e ações (SANTOS, 1978; 1988; 1996).

A seletividade espacial, nesse sentido, só pode ser compreendida em relação a uma dada formação socioespacial, podendo variar conforme a escala, do local ao global. O próprio autor aplicou o conceito para estudar a geografia urbana (SANTOS, 1993) ou a estrutura regional brasileira (SANTOS e SILVEIRA, 2011). Para fazer isso, todavia, era necessário um conceito que permitisse compreender a totalidade e indissociabilidade de todas as formas e conteúdos e sua natureza seletiva dentro da estrutura capitalista de produção. Esse é o contexto da apresentação do "território usado" como categoria de análise espacial, num momento em que o autor percebe a 
necessidade de tornar o conceito de espaço (e de formação socioespacial) uma teoria totalmente empiricizável.

O território usado torna-se, dessa forma, uma categoria de análise das seletividades espaciais, que produzem diferenciações socioespaciais entre os lugares, bem como espaços de privação social nas cidades. Para o autor, o território são as formas, "mas o território usado são os objetos e ações, sinônimo de espaço humano, espaço habitado" (SANTOS, 1994, p. 16). Por isso, o território usado comporta sempre uma dialética socioespacial, podendo também ser expresso como lugar de realização da vida. Em outros termos, segundo o autor, o território usado é o "espaço banal" que reúne todas as ações e todos os objetos sistemicamente.

A ideia de espaço banal, influenciada da teoria de mesmo nome desenvolvida por François Perroux, e aplicada por Jacques Boudeville, é o espaço que comporta, dentro de uma mesma lógica interna, todos os elementos presentes, como: os homens, as empresas, as instituições, as formas sociais e jurídicas e as formas geográficas, etc. (SANTOS, 2017). A noção de espaço banal, ou seja, espaço de todos os alcances, de todas as determinações, de todos os homens, deve ser entendida em oposição a ideia de rede, pois esta se constitui em apenas uma fração do espaço, o espaço de alguns, ou seja, da seletividade (SOUZA, 1999).

Assim, o território, em tempos recentes, pode ser formado de lugares contíguos, da solidariedade, e de lugares em rede, da seletividade e segregação. "Esta preposição nos remete a dialética do território: um controle local de parcela técnica da produção e um controle remoto de parcela política da produção" (SOUZA, 1999, p. 4). Estes são, entretanto, os mesmos lugares que formam redes e que formam o espaço banal.

As redes constituem uma realidade nova que, de alguma maneira, justifica a expressão verticalidade. Mas além das redes, antes das redes, apesar das redes, depois das redes, com as redes, há o espaço banal, o espaço de todos, todo o espaço, porque as redes constituem apenas uma parte do espaço e o espaço de alguns (SANTOS, 1994, p. 16).

Desse modo, alguns conceitos se tornam relevantes para a compreensão detalhada do território usado. Um dos mais importantes é a compreensão da divisão 
territorial do trabalho, que varia conforme uma dada formação socioespacial. Mas a compreensão da divisão territorial do trabalho exige considerar não apenas a realidade presente, mas também o processo histórico. No presente temos, segundo o autor, uma divisão do "trabalho vivo", mas suas ações são feitas sobre sucessivas divisões territoriais do "trabalho morto". A essas sucessivas heranças do "trabalho morto" o autor chama de rugosidades. As rugosidades são assim representadas por todas as formas materiais herdadas de outros momentos históricos, que nos tempos atuais obedecem a uma nova lógica funcional (SANTOS, 2017).

O território é formado por novas e velhas estruturas, que se cristalizam no espaço, defrontando-se com novos momentos históricos, que trazem novas ações e novos modos de produção. A rugosidade é o que fica do passado como forma, espaço construído, paisagem, o que resta do processo de supressão, acumulação, superposição com que as coisas se substituem e acumulam em todos os lugares (SANTOS, 2017). Esse embate entre as antigas formas herdadas no espaço e os novos equipamentos implementados, contribuem, portanto, para a diferenciação territorial, assim como ajudam na compreensão da realidade atual dos territórios.

A análise do território através dos seus usos tornou-se um instrumento importante para a pesquisa geográfica, sobretudo para os trabalhos de Geografia Urbana. Os usos do território expõem as contradições históricas que se materializam no espaço, e ainda permite a compreensão de determinados fenômenos socioespaciais, como a pobreza urbana, a privação social, a seletividade e as desigualdades sociais em geral.

Nessa acepção, o território usado é uma totalidade que só pode ser entendida em relação a uma dada singularidade, pois os processos históricos e a realidade presente são dados relativos a uma unicidade sistêmica, ou seja, o território usado é irreproduzível (único) e integrado nas escalas do acontecer social. Nessa linha de raciocínio, o objetivo deste artigo é analisar os usos do território urbano do Bairro Camobi, em Santa Maria, Rio Grande do Sul, nessa perspectiva da unicidade e da singularidade própria do conceito. Para isso e de maneira operacional, propõem-se: a) avaliar a construção histórica e geográfica do Bairro universitário Camobi, desde o 
período de Distrito rural de Santa Maria, RS, até os dias atuais; b) identificar as seletividades produtoras das desigualdades socioespaciais do Bairro, através da perspectiva dos usos do território, interpretados historicamente, e como eles influenciam na diferenciação das classes sociais no espaço do Bairro atualmente.

\section{METODOLOGIA}

Primeiramente recorreu-se ao levantamento bibliográfico, para melhor compreensão acerca dos usos do território ao longo do tempo no Bairro Camobi. Buscou-se a literatura a respeito do Bairro, resgatando os estudos realizados anteriormente, como de Klarmann (1990), Becker (1996), Spiazzi (2002), Comin (2008); (2013), o que contribui para o entendimento da construção histórica do espaço de Camobi. A legislação urbana encontrada nos sites do Instituto de Planejamento de Santa Maria (IPLAN) e da Prefeitura Municipal de Santa Maria (PMSM) também foi utilizada.

Os estudos do Bairro, bem como a legislação urbana, foram utilizados para a realização de uma periodização histórica e geográfica, identificando as diferentes formas de uso do território de Camobi ao longo do tempo. A ideia de período e de periodização constitui um avanço na busca da união espaço-tempo, ou seja, para entender o território, no seu processo e na sua realidade atual, "[...] um esforço de periodização é essencial" (SANTOS e SILVEIRA, 2011, p. 23).

A coleta de dados foi dividida em duas etapas. A primeira corresponde ao levantamento dos dados do Censo Demográfico de 2010, na plataforma online do Instituto Brasileiro de Geografia e Estatística (IBGE, 2010). Foram obtidas tabelas com variáveis de renda da população, escolaridade, bem como dados correspondentes às características dos domicílios do Bairro, ao nível dos setores censitários.

A segunda etapa correspondeu aos trabalhos de campo realizados no Bairro Camobi, que auxiliaram para o conhecimento in loco da área em estudo. Os campos foram realizados com o uso do método observacional (MINAYO, 2000), que consiste 
em uma técnica simples e eficiente, para reconhecimento dos usos e variações do território (FARIA, 2012).

Assim, foram utilizadas duas técnicas em campo: a coleta de dados fotográficos e o registro das informações com diário de campo. Para isso, foram realizados dez trabalhos de campo na área urbana do Bairro, ocorridos entre os anos de 2016 e 2019, que compreenderam todas as porções de Camobi, como podem ser visualizados no quadro 1.

\section{Quadro 1 - Trabalhos de campo no Bairro Camobi, Santa Maria, Rio Grande do Sul}

\begin{tabular}{|c|c|c|}
\hline$N^{\circ}$ de Campos & Data & Áreas percorridas \\
\hline $1^{\circ}$ & $17 / 04 / 2016$ & Norte e Central \\
\hline $2^{\circ}$ & $22 / 08 / 2016$ & Sul e Sudoeste \\
\hline $3^{\circ}$ & $27 / 07 / 2017$ & Sudoeste e Oeste \\
\hline $4^{\circ}$ & $31 / 07 / 2017$ & Central \\
\hline $5^{\circ}$ & $03 / 08 / 2017$ & Central \\
\hline $6^{\circ}$ & $05 / 08 / 2017$ & Leste \\
\hline $7^{\circ}$ & $17 / 08 / 2017$ & Norte \\
\hline $8^{\circ}$ & $23 / 03 / 2018$ & Leste e Norte \\
\hline $9^{\circ}$ & $22 / 08 / 2019$ & Sul, Sudoeste, Oeste, Norte e Central \\
\hline $10^{\circ}$ & $03 / 09 / 2019$ & Sul, Sudoeste e Norte \\
\hline
\end{tabular}

Organização: Os autores (2019).

Os dados coletados em campo referem-se à localização de condomínios fechados, os edifícios verticais, as unidades residenciais, as unidades industriais, as áreas verdes públicas (praças), além das ocupações irregulares. A coleta desses usos ocorreu com receptor GPS Garmin Extrex 30. Posteriormente, os dados foram tratados e categorizados com a utilização do software QGIS, versão 2.18.28.

Para os mapas de rendimento nominal mensal e de analfabetismo do Bairro, utilizou-se os dados não-espaciais (tabelas), por setores censitários, advindos do Censo Demográfico de 2010. Os dados foram associados a representação poligonal georreferenciada por meio do código dos setores censitários e o intervalo de classes usou-se o modo de quebras naturais (Jenks). Os mapas foram finalizados no novo compositor de impressão do QGIS. 


\section{CARACTERIZAÇÃO HISTÓRICA E GEOGRÁFICA DO BAIRRO CAMOBI}

Camobi é um Bairro localizado na porção leste da cidade de Santa Maria, Rio Grande do Sul, com uma população que, em 2010, era de 21.822 habitantes (IBGE, 2010) (figura 1). Devemos, antes de tudo, situá-lo em relação à cidade de Santa Maria, essa "capital regional"i localizada no interior do estado do Rio Grande do Sul. Santa Maria é uma cidade média de cerca de 278.445 habitantes (SANTA MARIA, 2018), surgida e constituída historicamente como uma cidade político-militar, universitária e de oferta de bens e serviços para uma hinterlândia regional. O trabalho de Rocha (1993) a define ainda como um centro de drenagem de uma renda fundiária regional, cuja relação econômico-agrária é relativamente comum nas cidades médias do interior.

Segundo Degrandi (2012), Santa Maria pode ser definida pela sobreposição e coexistência histórica de quatro diferentes usos do território: o uso militar, o uso ferroviário, uso universitário e o uso comercial e de serviços ou coorporativo. Nas palavras do autor, a formação e produção do território de Santa Maria

[...] tem em suas bases a acumulação de outros eventos de diferentes tempos, uns fortalecidos por suas próprias dinâmicas, outros como rugosidades que resistem às modernidades contemporâneas. Reafirmamos, assim, que os principais usos do território foram aqueles que o imaginário popular atribuiu como cognomes de Santa Maria: cidade militar, cidade ferroviária e cidade universitária. Reconhecemos e demonstramos, ao longo da pesquisa, que foram estes os principais usos que, ao se acumularem no território, criaram as condições para que ele, no presente, viesse acolher as modernidades da globalização e a consolidar-se como capital regional, destacadamente em sua função comercial (DEGRANDI, 2012, p. 268-269).

Genericamente podemos dizer que o Bairro Camobi reproduz esses quatro tipos de uso do território definidores da área urbana de Santa Maria como um todo, com particular importância para os usos universitário e militar, pois ali está a Universidade Federal de Santa Maria (UFSM) e a Base Aérea de Santa Maria (BASM). Entretanto, outras formas de usar o território de Camobi foram utilizadas ao longo da história do Bairro, principalmente o ferroviário, que determinou a dinâmica econômica por longo tempo. Nesse sentido, para adentrar na formação socioespacial desse território, optou-se por uma breve periodização que abrange, sinteticamente, os três 
momentos principais do Bairro: primeiro como distrito rural de Santa Maria, posteriormente, com a instalação das instituições públicas, ou seja, Universidade Federal e Base Aérea, e o momento atual, que se desenvolve desde a consolidação de Camobi como Bairro.

Figura 1 - Localização do Bairro Camobi, Santa Maria, Rio Grande do Sul.

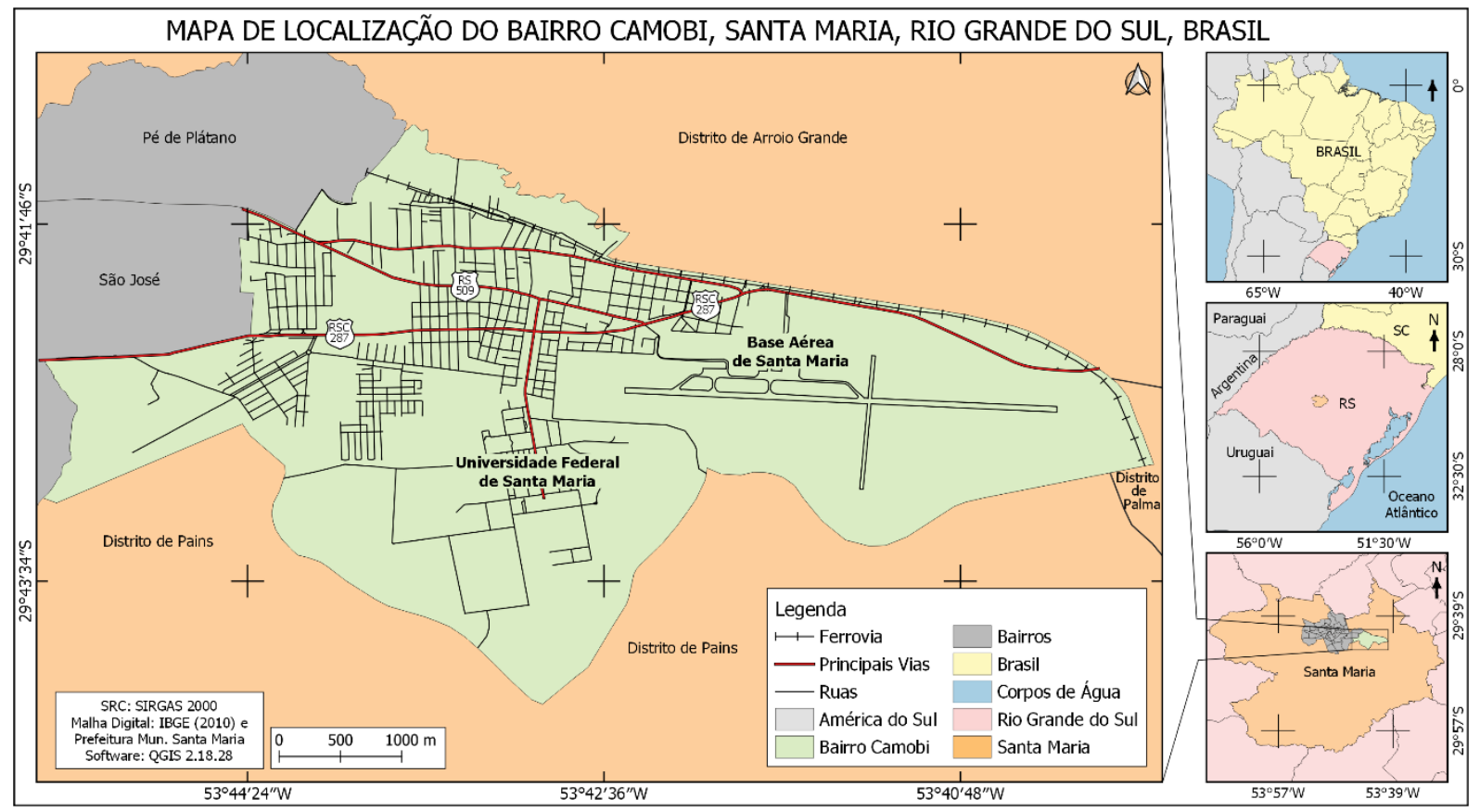

Elaboração: Os autores (2019).

\subsection{Bairro universitário Camobi: em busca de uma periodização}

A formação inicial do território que viria a se tornar o Bairro Camobi, deu-se através da chegada de imigrantes italianos, no final do Século XIX, procedentes, principalmente, da colônia de Silveira Martins, estes que, se fixaram nas regiões de Arroio Grande e São Sebastião (COMIN, 2013). Muito embora, em momento anterior, imigrantes poloneses houvessem também ocupado esse território, mesmo que por pouco tempo (COMIN, 2013).

Desse modo,

Este local foi denominado pelos imigrantes italianos de Estação Colônia. No local deste povoamento foi instalada, em 1885, a estação ferroviária que passou a ser local de atração para as pessoas e, principalmente, de concentração e distribuição de mercadorias. Nesse período, a Estação Colônia funcionava como um empório 
colonial, pois neste local se concentrava a produção agrícola da região. Essa produção escoava, principalmente, para Porto Alegre. A instalação da Viação Férrea do Rio Grande do Sul (VFRGS) consistiu num avanço para o transporte de cargas e passageiros, trazendo dinamismo ao lugar (COMIN, 2013, p. 76).

Em um contexto que Santa Maria se tornava o principal entroncamento ferroviário no centro do Rio Grande do Sul, a estação ferroviária, implantada no então distrito de colônia, ganhou importância fundamental para o desenvolvimento do distrito, com a circulação de pessoas e mercadorias. Portanto, o uso ferroviário do território altera a dinâmica local. De acordo com Klarmann (1990, p. 27) “historicamente, a ocupação inicial do Bairro esteve ligada a ferrovia, com sua estação ferroviária polarizando o desenvolvimento da antiga sede do distrito de Colônia (hoje Camobi)".

O distrito de Colônia, então $3^{\circ}$ distrito de Santa Maria, nesse período, é um dos mais prósperos do município, tendo suas atividades ligadas principalmente ao uso ferroviário, embora sua população fosse prioritariamente rural (COMIN, 2013). Essa foi a realidade do distrito durante a primeira metade do Século $X X$, baseado em atividades rurais, e tendo como ponto de distribuição de mercadorias e circulação de pessoas a estação ferroviária, localizada a Norte de Camobi. A principal via rodoviária, nesse período, era a Avenida João Machado Soares (figura 1), paralela à estrada de ferro, avenida que por muito tempo foi a principal norteadora da ocupação do Bairro (COMIN, 2008).

Essa realidade passou a ser alterada no primeiro momento pelo enfraquecimento do sistema ferroviário em todo o país, em meados da década de 1950, e em especial Santa Maria, e no segundo momento com a instalação de outros importantes objetos no espaço do distrito de Camobi, que passaram a alterar os usos do território no local. O primeiro deles, a UFSM, criada em 1960, posteriormente, a BASM, dez anos mais tarde (KLARMANN, 1990).

Desse modo, é possível constatar que, apesar de haver circulação de pessoas e mercadorias no distrito, é somente após a segunda metade do século $\mathrm{XX}$, com os novos usos do território (universitário e militar), que se inicia, mesmo que ainda de modo lento, a urbanização e expansão territorial de Camobi (COMIN, 2013). Isso se 
expressa, de maneira geral, pelo aumento do fluxo de população que se fixa no distrito, para funções ligadas ao uso universitário e militar, ao passo que as atividades ligadas à ferrovia entram em decadência.

Assim, a principal via do distrito de Camobi naquele contexto, a Avenida João Machado Soares, deixa de polarizar as principais atividades econômicas, estendendose agora para a RS-509, denominada Avenida Prefeito Evandro Behr ou RS-509 (figura 1). A partir desse momento, a função da RS-509, conhecida atualmente por Faixa Velha de Camobi, é caracterizada por atividades comerciais, indústrias e setor de prestação de serviços (KLARMANN, 1990).

Com a instalação da UFSM e a BASM na região Sul do distrito, tornam-se mais densos e diversificados os usos do território. De fato, até a metade do século XX, as atividades econômicas e de serviços estavam concentradas na porção Norte de Camobi, nas proximidades da ferrovia. Simultaneamente, o declínio ferroviário e a criação da universidade, são fatores relevantes para uma desconcentração populacional e de atividades econômicas, isto é, do Norte para o Sul, visto que, na proximidade do campus universitário há gradativo aumento da demanda e, consequentemente, do valor da terra. Segundo relata Comin (2008), a partir desse período inicia-se o processo de especulação imobiliária em Camobi, em vista do aumento populacional do distrito, constituído, principalmente de pessoas que trabalhavam nas instituições (UFSM e BASM) e que passam a fixar residências no local. Dessa maneira, acirra-se o processo de produção capitalista do território de Camobi, com o aumento no número de loteamentos, abertura de vias e divisão da terra em lotes, para posterior venda (SPIAZZI, 2002); (COMIN, 2008).

Com o aumento da importância política e econômica do distrito nesse período, surgem rumores de uma possível municipalização do território de Camobi (SPIAZZI, 2002), tendo em vista o desenvolvimento causado pelas instituições instaladas no distrito, principalmente a UFSM. De acordo com Spiazzi (2002), isso se "atenta aos anseios emancipacionistas dos moradores e autoridades do Distrito e visando evitar a emancipação, a Prefeitura Municipal de Santa Maria, ampliou o perímetro urbano da cidade, englobando a então área de Camobi" (SPIAZZI, 2002, p. 15). 
Desse modo, a primeira medida tomada, nesse sentido, ocorre em 1979, com a ampliação da área urbana da cidade, que incorpora a sede do então distrito de Camobi a área urbana de Santa Maria. A segunda medida se dá através da Lei Municipal no 2.410/82 (SANTA MARIA, 1982), a qual estabelece a divisão de Santa Maria por Bairros. Em termos práticos, portanto, altera-se o estatuto jurídico, passando de distrito para Bairro Camobi (COMIN, 2013). Com a resolução da nova Lei municipal de No. 2770/86 de 02 de julho de 1986 (SANTA MARIA, 1986), que alterou o perímetro urbano, e dispôs sobre as denominações dos Bairros de Santa Maria, Camobi passou a contar com as seguintes unidades residenciais: Vila Soares do Canto, Parque Residencial Universitário, Parque Residencial Fiori D'Italia, Vila Operária, Vila Santa Helena, Vila Assunção, Vila Tereza, Vila Santos Dumont, Base Aérea de Santa Maria, Condomínio Vila Verde, Parque Alto da Colina, Pettit Village e Vila Jardim. Essa divisão vigorou até o ano de 2006, quando uma nova divisão foi apresentada através da Lei $n^{\circ}$ 042/2006, ficando Camobi com as seguintes Unidades Residenciais ilustradas na figura 2.

Figura 2 - Unidades Residenciais do Bairro Camobi, Santa Maria, RS.

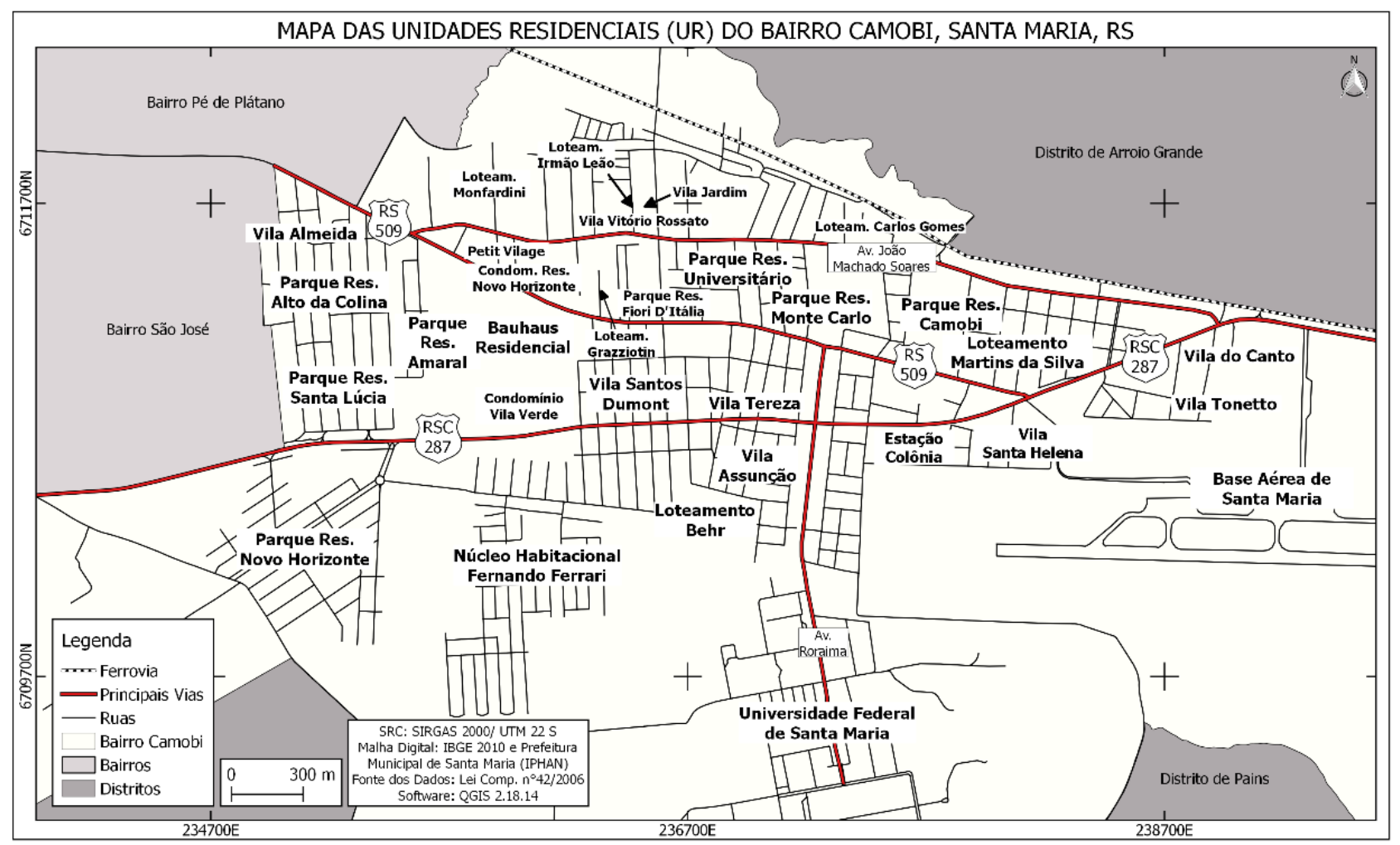

Fonte: Spode (2017). 
Figura 3 - (A) Edifício em construção na avenida Roraima em 2017; (B) rugosidade na área central de Camobi; (C) início das obras de edifício na avenida Prefeito Evandro Behr (RS509) - Faixa Velha e (D) fim do dia em Camobi - Faixa Velha.

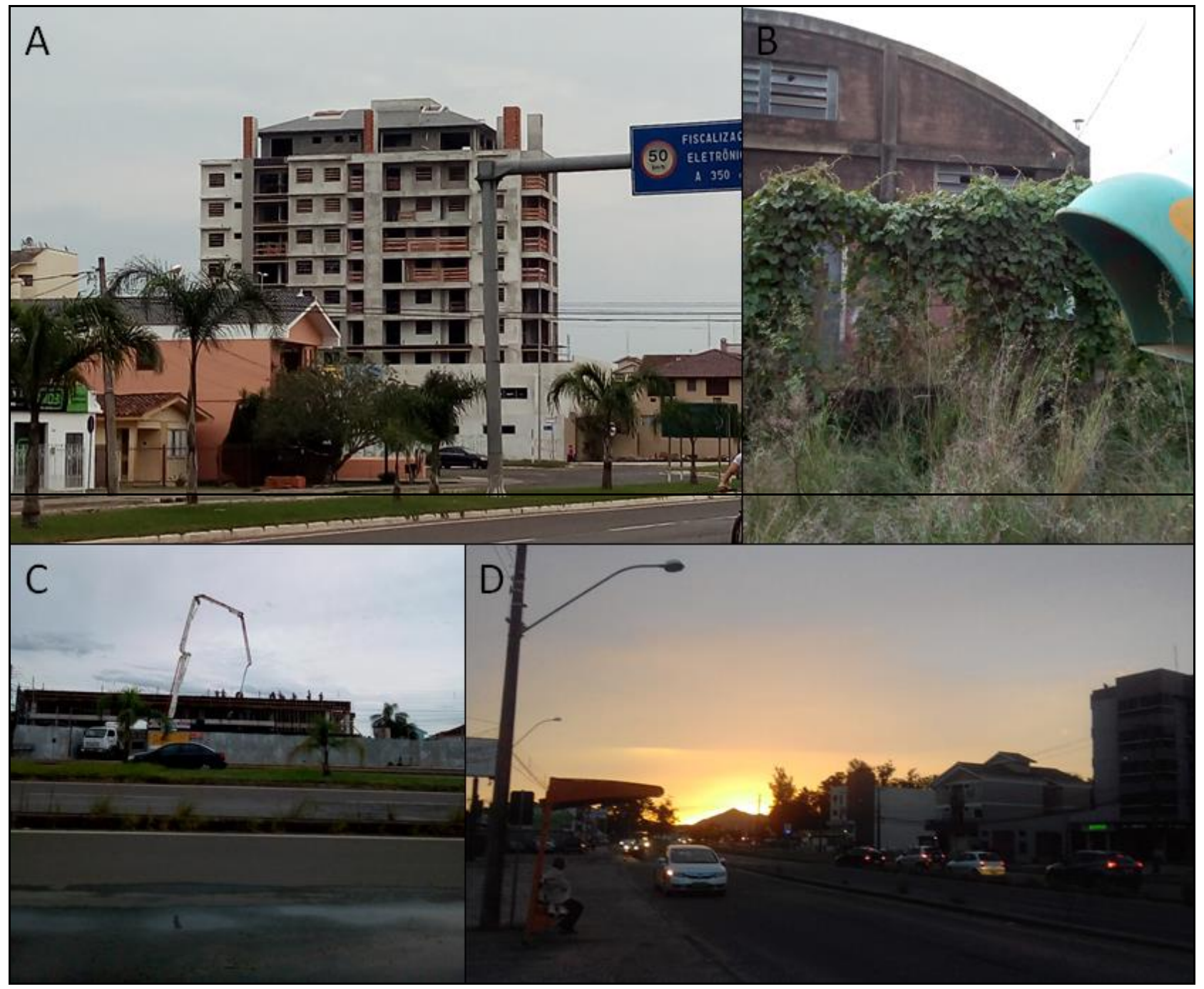

Fonte: Acervo particular dos autores (2017, 2018 e 2019).

A mudança do estatuto jurídico do Bairro foi, dessa forma, uma resposta ao processo de urbanização, para além das relações de poder político. Isso assinala profundas mudanças espaciais, num momento, ainda década de 1980, de crescimento populacional, aumento das funções urbanas, mas ainda com manutenção de atividades agrárias próprias da pretérita vida distrital. Por isso, ainda na década de 1980, tem-se a instalação da COHAB Fernando Ferrari (figura 2), que foi primeiro conjunto habitacional do Bairro Camobi. Esse conjunto habitacional popular, além da construção da BR-287, a "Faixa Nova" de Camobi, como é popularmente conhecida, 
determinaram a expansão territorial para as imediações da UFSM, consolidando o Bairro "[...] como núcleo mais importante fora da zona central" (ROCHA, 2011, p. 383). Atualmente, a dinâmica urbana de Camobi se dá através da sobreposição de formas de uso do território, balizados principalmente pelos usos universitário e militar, que impulsionam a produção capitalista do espaço do Bairro, sobretudo em investimentos imobiliários. Esses investimentos são materializados na forma de prédios de moradia e comerciais, condomínios, loteamentos, entre outros objetos facilmente identificáveis no território de Camobi.

Além disso, o fluxo de pessoas e veículos todos os dias no Bairro, entre automóveis, ônibus urbanos e intermunicipais, caminhões, motocicletas, bicicletas, etc., em duas vias que possuem estrutura defasada, dão a dinâmica da circulação econômica em Camobi, que hoje, para muitos, atua como local de trabalho e ou estudo, refletindo uma população flutuante numerosa. Os congestionamentos, nas vias citadas, são recorrentes, principalmente pela manhã e no fim do dia. A figura 3 ilustra alguns aspectos da área central do Bairro atualmente.

\section{USOS DO TERRITÓRIO NO BAIRRO CAMOBI}

Camobi, em tempos atuais, apresenta-se como um Bairro heterogêneo, com diversas formas sobrepostas de uso do seu território. Em primeiro lugar, o uso universitário, através da dinâmica imposta pela Universidade Federal e a Base Aérea, assim como os usos ferroviários, hoje em forma de rugosidades e territórios privados dentro do Bairro. Em segundo lugar e como consequência destes, os usos ligados aos serviços e comércio oferecidos para uma população acadêmica e de servidores públicos. Finalmente, os usos residenciais, na forma de condomínios ou não, verticais ou horizontais, que respondem por uma economia importante produzida pelo setor imobiliário.

O mapa da figura 4 apresenta uma síntese parcial dos principais usos do Bairro Camobi. Essas formas de uso do território são derivadas dos objetos instalados ao longo da história no Bairro e ressignificados na vida presente pela criação de novos 
objetos e novas ações (SANTOS, 2017). Essa densidade e diversificação, que resulta da própria divisão territorial do trabalho, resulta em usos do território que variam entre os condomínios residenciais horizontais e verticais, ocupações irregulares, áreas públicas de lazer, estruturas de fluxos (rodovias, ferrovia), entre outros.

Figura 4 - Mapa dos usos do território no Bairro universitário Camobi, Santa Maria, RS.

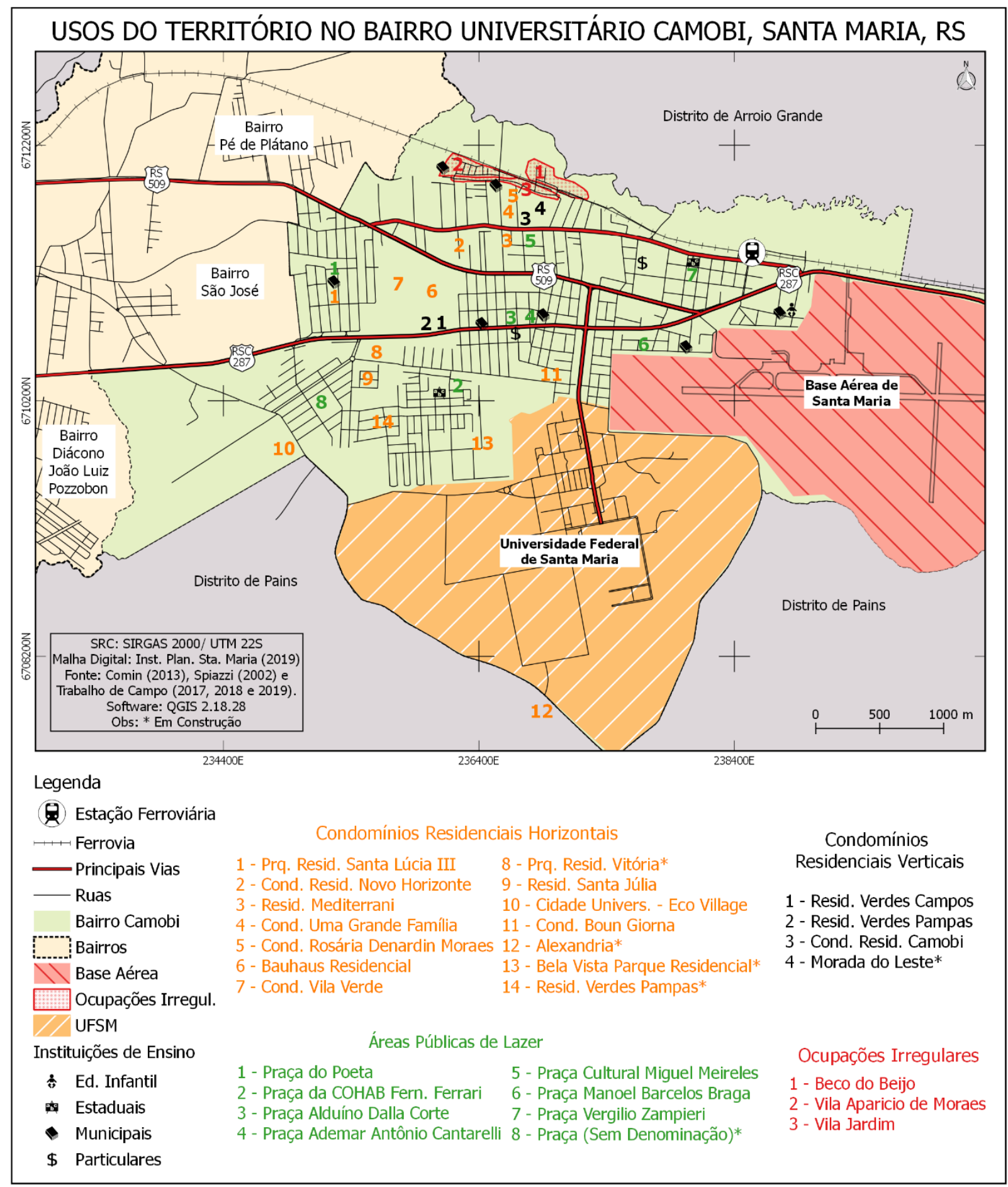

Elaboração: Os autores (2019). 
Essa densificação resulta e revela a heterogeneidade nos usos do Bairro, com áreas de condomínios fechados de alto padrão, coexistindo, na mesma unidade espacial, com populações pobres e privadas, residindo em habitações relativamente precárias. Comin (2013), ao estudar a segregação residencial no Bairro, aponta que as tipologias habitacionais estão representadas por classes sociais bem expressivas no território de Camobi,

a que reside em áreas de ocupação irregular, representando as classes de baixa renda e outra representando a elite que reside em condomínios horizontais fechados de uso residencial e manchas da classe média. No entanto, apresentam proximidade geográfica e distanciamento social imposto por muros, cercas elétricas e fortes esquemas de segurança (COMIN, 2013, p. 118).

Embora a segregação residencial esteja presente, como bem retratou a autora, os usos do território em Camobi se apresentam de maneira complexa, com os grupos sociais distribuídos de forma heterogênea no espaço, havendo locais onde se sobrepõem mais de uma lógica territorial. No entanto, para efeito de análise, três áreas de Camobi serão destacadas com maior profundidade: a porção Norte do Bairro, que se estende paralela aos trilhos, a área Central, próximas da UFSM, e a porção Oeste.

A área Norte de Camobi compreende a faixa ao longo da estrada de ferro, onde localizam-se o Loteamento Irmão Leão, Vila Vitório Rossato, além das áreas de ocupação irregular Aparício de Moraes, "Beco do Beijo" e Vila Jardim (ver mapa da figura 4). Estas áreas a Norte do Bairro compreendem o núcleo de povoamento inicial, conhecido como "Camobi antigo", lócus da produção econômica local até meados da metade do século $X X$.

Entretanto, no contexto atual, elas perderam importância para outras áreas, sobretudo as mais próximas da UFSM. A Vila Tonetto, por exemplo, área próxima à estação ferroviária, tem sua formação anterior à Viação Férrea (1885) (COMIN, 2013). Portanto, a área Norte é marcada por um uso cuja densificação e diversificação é dada pela sua remota idade. 
Figura 5 - Mapa da porcentagem dos domicílios particulares conforme seu rendimento nominal mensal: até 1 salário (A) e maior igual que 5 salários mínimos (B) do Bairro Camobi, Santa Maria, RS, por setor censitário.

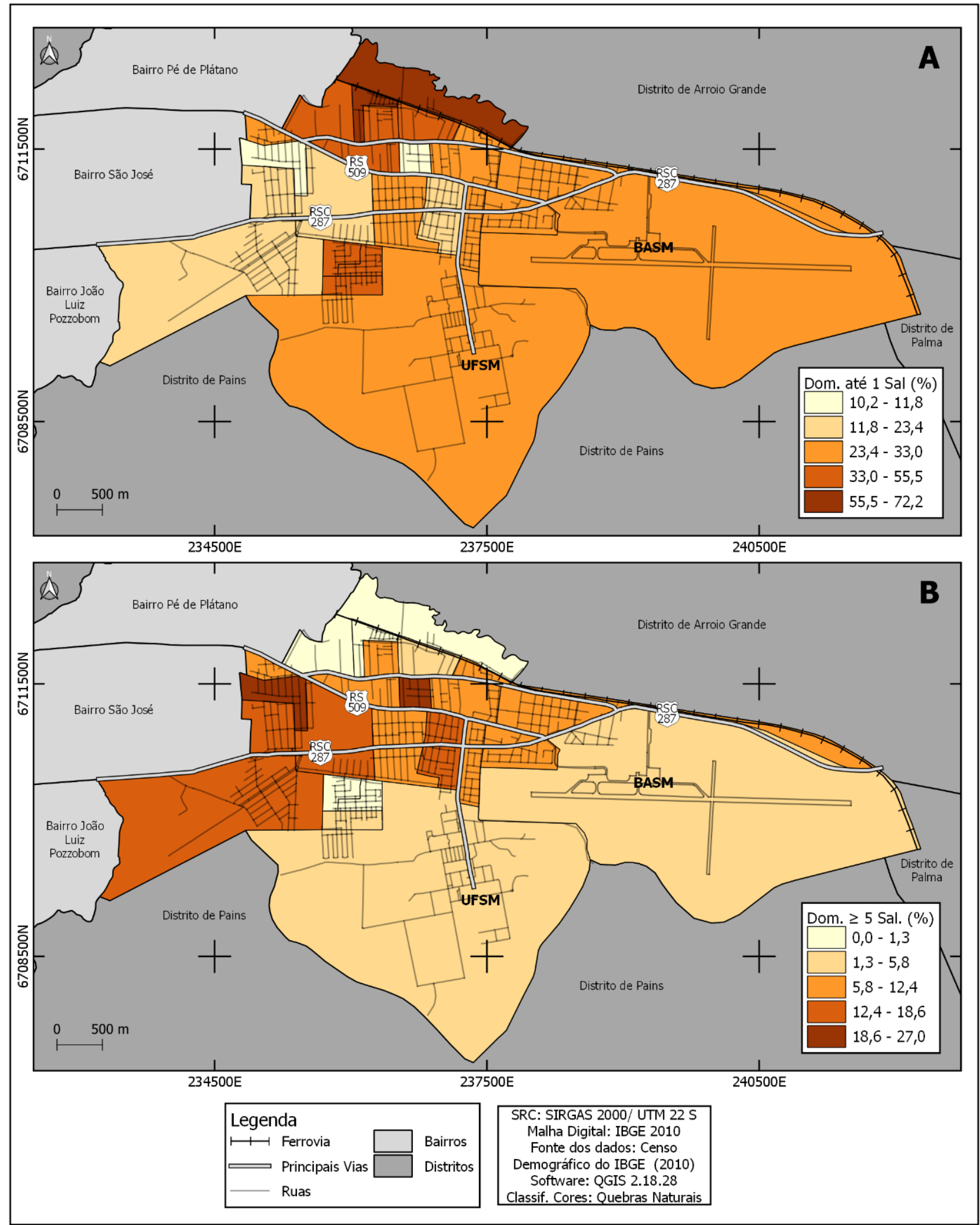

Elaboração: Os autores (2019). 
Uma forma de compreender ou empiricizar os processos sociais consequentes dessas diferentes densificações e diversificações é através do mapa da renda. Embora se trate de um indicador criticado pela sua arbitrariedade, a literatura o reconhece como uma fonte produtora de privações sociais (sendo ele mesmo uma privação que produz privações) (SEN, 2010). Vejamos essa "Geografia da renda" no mapa figura 5.

Observe-se que a renda ilustra bem a transformação espacial do Bairro, com os usos do território seguindo o traçado da distribuição da renda em Camobi, que tende a tornar-se mais alta nas áreas próximas à UFSM e à Oeste do Bairro.

Conforme as atividades ferroviárias foram perdendo o destaque, e com a instalação do campus da UFSM, o lócus econômico migrou, pouco a pouco, para as vias citadas, principalmente a RS-509, conhecida como faixa velha de Camobi (KLARMANN, 1990; COMIN, 2008; RIZZATTI et al, 2017; SPODE, 2017).

Rizzatti et al (2017, p. 2996) em estudo sobre os aspectos populacionais do Bairro, haviam destacado que a "população com maior renda está concentrada entre as principais rodovias de Camobi (faixa nova e velha), e essa variável diminui em direção ao Norte do Bairro, próximo à ferrovia". Assim, se de um lado as áreas mais próximas da Universidade Federal tornam-se espaços da seletividade, com grandes obras de condomínios fechados e edifícios verticais, que fazem uso do território a partir da lógica do capitalismo financeiro contemporâneo, de outro, territórios de pobreza e privação social, como nas áreas à Norte de Camobi.

É na porção Norte que se identificam os principais problemas socioespaciais, principalmente no que tange a infraestrutura urbana, como a deficiência de pavimentação das ruas e inexistência de saneamento básico adequado. Nessa região estão localizadas, atualmente, três áreas onde historicamente ocorrem ocupações irregulares, sendo elas a vila Jardim, a vila Aparício de Moraes e o Beco do Beijo (figura 4), conforme os dados levantados em campo e também fornecidos pelo Instituto de Planejamento de Santa Maria. Esses problemas foram identificados por Spiazzi (2002, p. 44), que tendo como foco de análise as Vilas Jardim e Aparício de Moraes, relata da seguinte maneira a questão do saneamento nestas áreas: 
Na Vila Jardim e Vila Aparício de Moraes, os esgotos domésticos são lançados a céu aberto, através das sarjetas sem calçamento ou em valas feitas pelos moradores para escoar a água da chuva, sendo os mesmos lançados no afluente do Rio Vacacaí-Mirim [...] (SPIAZZI, 2012, p. 44).

Cabe ressaltar que os problemas com relação ao saneamento básico são históricos e materializados em diversas áreas do Bairro, com predominância para a porção Norte e para a COHAB Fernando Ferrari, locais com histórico de ocupações irregulares desde a década de 1970. Cabe reiterar que desde a década de 1970 as ocupações irregulares vêm ocorrendo em Camobi (PRADO, 2010), principalmente se utilizando da terra desocupada no entorno dos trilhos ou nas áreas de transição do urbano para o rural.

Nos anos de 1990, Becker (1996) já mencionava sobre a inexistência de esgoto sanitário no Bairro, trazendo uma diferenciação nas condições de saneamento entre as ruas pavimentadas e as não pavimentadas. A autora expõe que nos casos onde a rua é pavimentada e possui rede de esgoto pluvial, os resíduos são despejados nesta rede. No entanto, em outras circunstâncias, o esgoto corre a céu aberto, causando mau cheiro e a proliferação de insetos (BECKER, 1996).

Cabe ressaltar que a questão do esgoto em Camobi, no contexto atual, ainda se apresenta como problema de ordem estrutural no Bairro, pois, as obras de saneamento básico iniciaram apenas em tempos recentes, e com alguns contratempos de natureza política-burocrática. No ano de 2014, após pouco mais de um ano de serviços, segundo matéria veiculada no site da Prefeitura Municipal de Santa Mariaii, $11 \%$ da rede de esgoto do Bairro estava concluída, ou seja, "dos 83 quilômetros previstos, apenas sete quilômetros de assentamento de tubulação foram executados neste período" (PRATES, 2014, s. p.). Alguns exemplos desses problemas podem ser visualizados em diversas áreas do Bairro, como demonstrado na figura 6. 
Figura 6 - Efluentes domésticos lançados diretamente na sanga Lagoão do Ouro - COHAB Fernando Ferrari (A e B), esgoto a céu aberto em uma importante via de Camobi (C) e rua sem pavimentação na área central do Bairro (D).

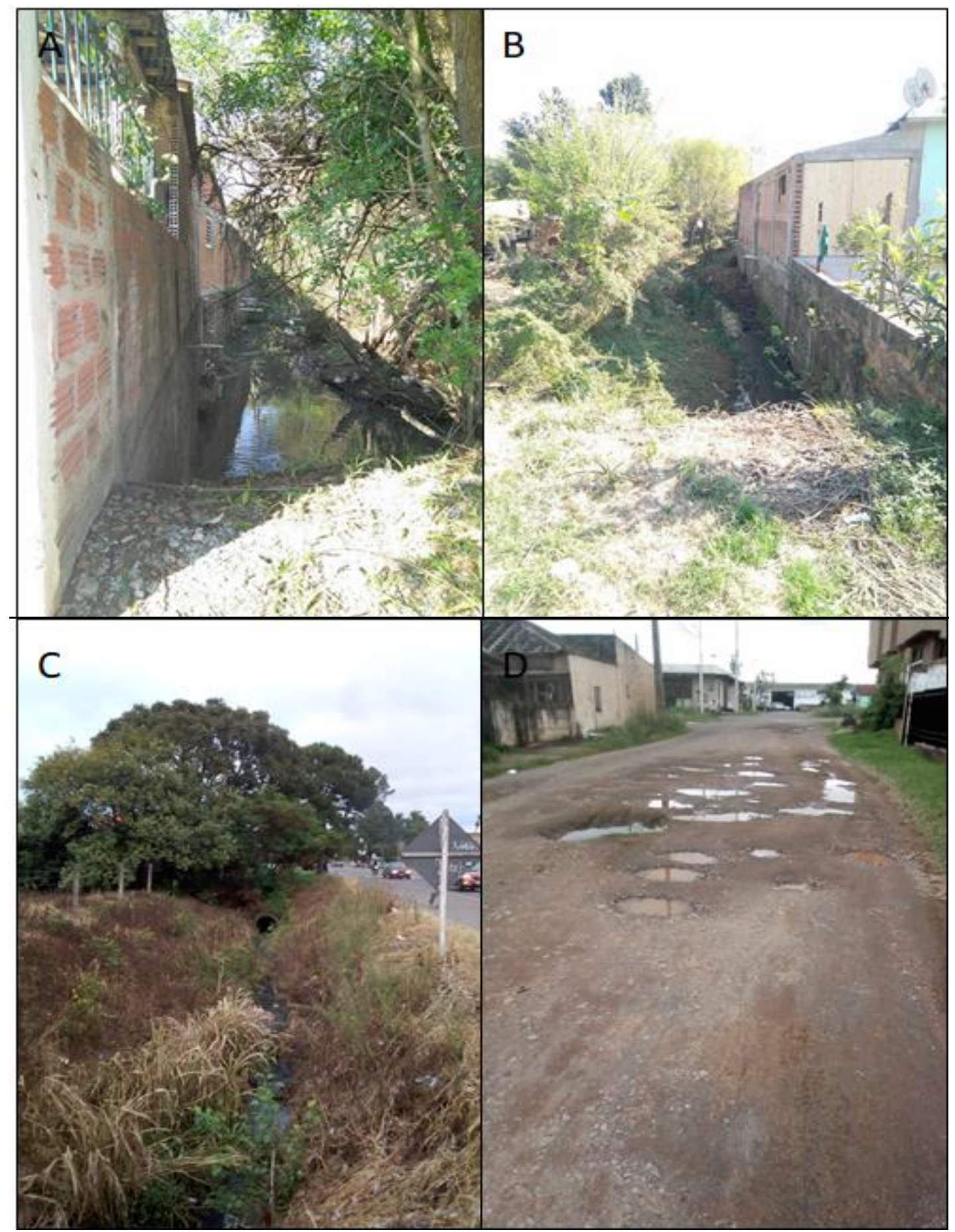

Fonte: RIZZATTI (2018) e Acervo particular dos autores (2017).

Ao observarmos o mapa de renda (figura 5), torna-se possível identificar uma área de renda baixa na parte Centro-Sul do Bairro, correspondente a COHAB 
Fernando Ferrari. A COHAB Fernando Ferrari é um "[...] conjunto habitacional que tinha como objetivo servir de moradia para funcionários da UFSM" (COMIN, 2013, p. 94). No entanto, como relata a autora, poucas residências mantêm sua fisionomia original, com a maioria delas tendo sofrido modificações, como ocorreu no que hoje se chama Núcleo Habitacional Fernando Ferrari. As imagens A e B da figura 6 retratam os problemas relacionados ao saneamento básico na COHAB, com o esgoto sendo despejado diretamente no curso de água.

Em contrapartida, grande parte da porção central e Oeste, segundo o mapa da figura 5-B, apresentam as rendas mais altas do Bairro. Os usos do território na porção central caracterizam-se pela concentração comercial e de serviços, principalmente ao longo da RS-509, a faixa velha de Camobi, que concentra grande parte dos edifícios verticais do Bairro.

Dessa maneira, a porção central de Camobi apresenta-se como polo da reprodução do capital, assim como da especulação imobiliária. Isso se dá pelo fato da grande procura por imóveis, sobretudo apartamentos, por parte de estudantes, professores, funcionários, militares, etc. Em trabalho realizado em 2017, foram contabilizados no período de julho e agosto, o total de 49 edifícios em construção no Bairro, no qual, 46 deles eram prédios residenciais (SPODE, 2017), ressaltando o uso da área central do Bairro, baseado, principalmente, na reprodução de edifícios de moradia.

A porção Oeste se caracteriza pela presença dos Parques Residenciais de médio e alto padrão, como o Parque Residencial Santa Lúcia, o Parque Alto da Colina e o Parque Residencial Novo Horizonte. Os condomínios horizontais de média e alta renda também estão presentes ao longo da zona Oeste do Bairro, como o condomínio Cidade Universitária - Eco Village, o Parque Residencial Vitória e o Residencial Santa Julia.

Somam-se ao total 11 condomínios fechados no território urbano de Camobi, a maioria deles de alto e médio padrão, dispondo de alta estrutura de segurança, como muros, cercas elétricas e segurança privada, além de áreas de lazer internas, como é o caso do Bauhaus Residencial, localizado na RS-509. De acordo com Comin (2013, p. 
102), "o condomínio Bauhaus possui uma área compreendida por 102 lotes residenciais de alto padrão de 500 a $1.700 \mathrm{~m}^{2}$, lotes estes diferenciados, de fácil acesso, distanciado apenas a 2 km da UFSM, e a 9 km do centro de Santa Maria". Outro exemplo de condomínio de alto padrão é o Alexandria, ainda em processo de construção, localizado na estrada municipal Silvio Schirmer (conhecida como acesso secundário ao campus de Camobi), próximo a Universidade Federal.

Desse modo, além da produção massiva de edifícios verticais na área central, também ocorre ampliação no número de condomínios no Bairro Camobi, o que segundo Comin (2013, p. 101) "[...] se deve em parte à dinâmica de expansão urbana produzida pelos promotores imobiliários, elegendo setores da cidade para valorização e expulsando, indiretamente, os grupos fragilizados de renda". Esse processo ocorre, também, na produção de edifícios na área central do Bairro, que com a valorização da terra urbana, acabam, de certa maneira, expulsando as populações de baixa renda que tradicionalmente habitavam o local. O uso do território, portanto, se dá através da reprodução do capital imobiliário, que altera as formas do Bairro e retira os mais pobres para áreas distantes e com pouca infraestrutura urbana. Isso é o que pode ser chamado de seletividade espacial.

\subsection{Bairro Camobi: Pobreza, privação e seletividade espacial}

Além da Universidade Federal, Camobi abriga 11 escolas de Ensino Fundamental e Médio, assim como inúmeras escolas de educação infantil e de idiomas. No entanto, ao identificar os dados referentes ao nível de escolaridade no Bairro, identifica-se áreas em que a população apresenta baixa escolaridade, sobretudo onde as rendas são baixas, como na parte Norte. Em um estudo da distribuição espacial da população, realizado por meio das variáveis do censo de 2010 do IBGE, Rizzatti et al., (2017) trazem dados a respeito do analfabetismo no Bairro, apontando a COHAB Fernando Ferrari e especialmente a área Norte como as mais privadas de educação. Em termos numéricos, os autores apontam, 
Segundo dados do censo demográfico do IBGE (2010), no setor censitário onde se localiza o Beco do Beijo há 172 analfabetos (18,40\% da população do setor censitário) e a leste deste local, na Vila Progresso, encontram-se 151 analfabetos (aproximadamente $14,3 \%$ da população do setor censitário). Já no setor localizado ao norte da ferrovia, o índice de analfabetismo chega a 15,5\% (RIZZATTI et al., 2017, p. 3000).

Isso revela uma das contradições do território de Camobi e de Santa Maria, em geral, pois embora possua a alcunha de "cidade universitária", o aparato educacional é seletivo apenas para parte da população da cidade, bem como de Camobi. O mapa de escolaridade das áreas de Camobi apresenta de forma bem clara essa diferenciação na escolaridade da população do Bairro, apontando as áreas de baixa renda a Norte, como áreas privadas de educação formal, com índice elevado de pessoas analfabetas. O mapa de escolaridade da população do Bairro pode ser observado figura 7 .

Figura 7 - Mapa da Taxa de Analfabetismo do Bairro Camobi, Santa Maria, RS, por setor censitário.

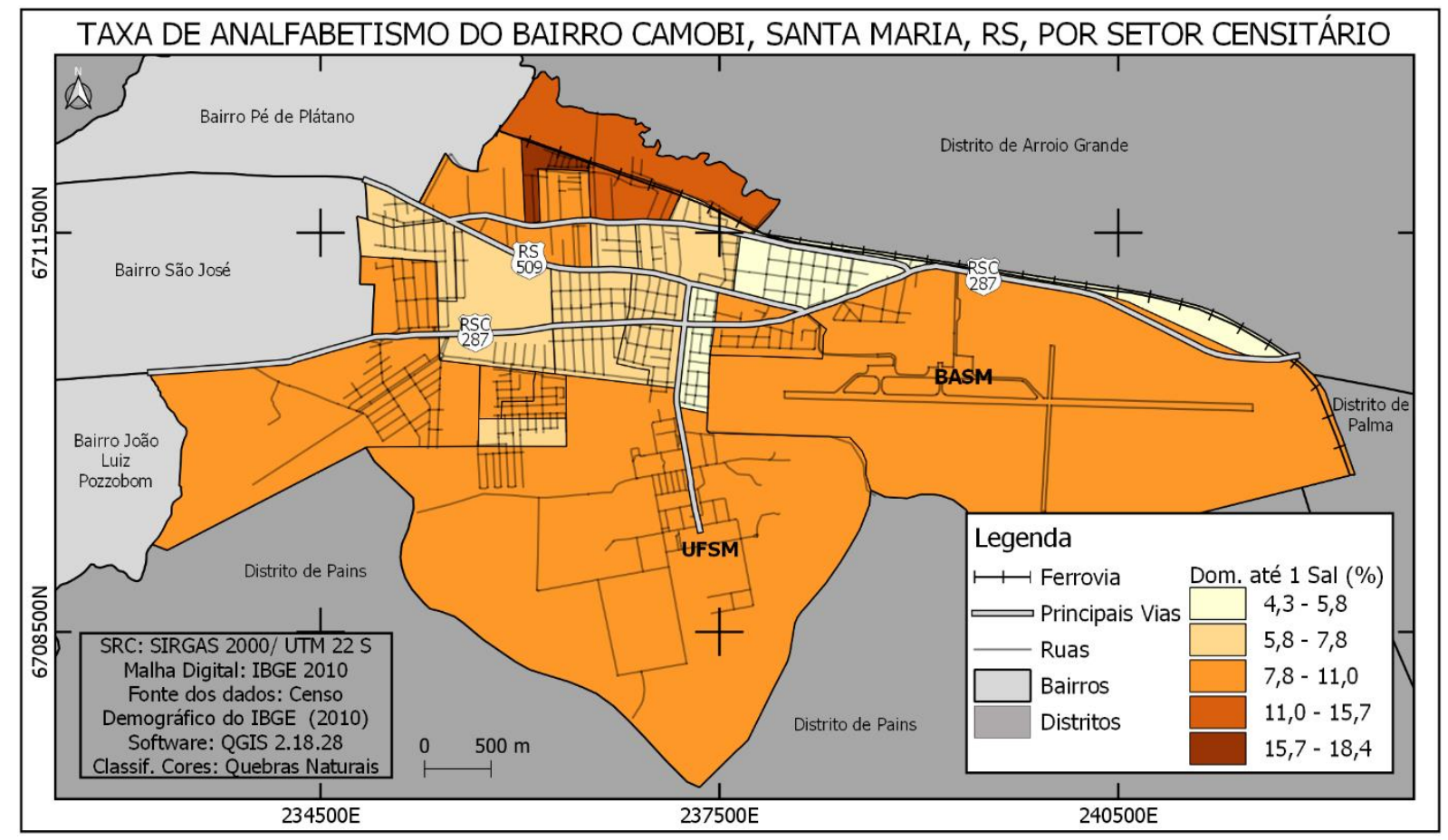

Elaboração: Os autores (2019).

Na área Norte, no conjunto de rugosidades ferroviárias, apresentam-se porções de pobreza no território de Camobi, ressignificando as funções dos equipamentos 
ferroviários, sobretudo pela ocupação irregular de terras públicas devolutas no seu entorno. Se é verdade que a linha de ferro ainda seja utilizada em pequena escala por trens de carga, é verdade também que sua forma não se renovou como uma possibilidade de desenvolvimento espacial. De tal modo que, em relação à dialética das formas-conteúdo, trata-se de um complexo aglomerado e aglomerador de pobreza. Portanto, paradoxalmente, o uso ferroviário, que na primeira metade do século XX determinou o desenvolvimento do então Distrito de Camobi, atualmente se comportam como marcas de outro tempo materializadas no espaço, que se caracterizam como territórios de pobreza e privação social. Esses registros podem ser melhor visualizados na figura 8.

Figura 8 - Residências abandonada na área Norte de Camobi (A e B); antiga estação ferroviária de Camobi (C); antiga estrutura de carga e descarga de grãos (ainda em uso) (D).

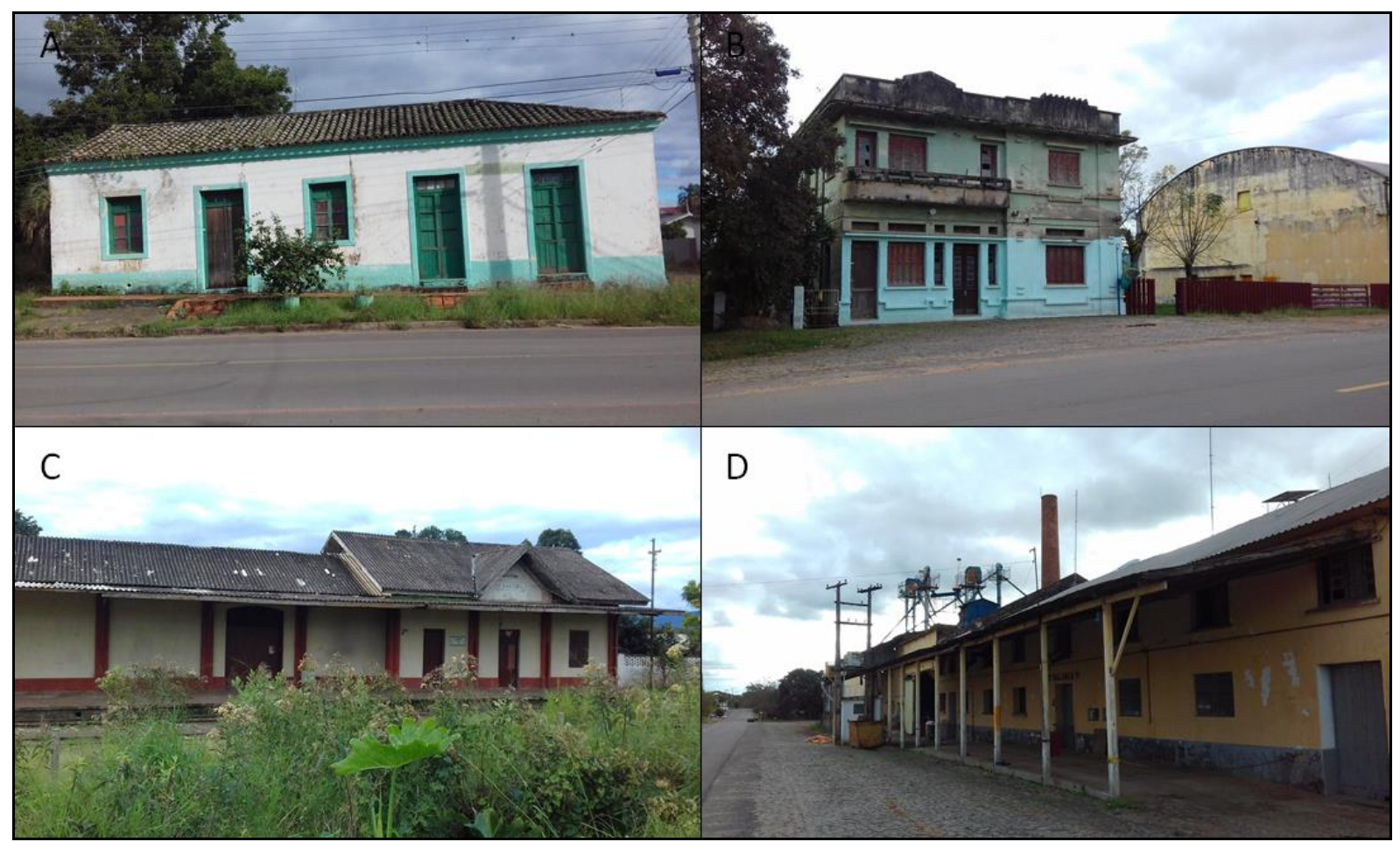

Fonte: Acervo particular dos autores (2019).

O mapa de analfabetismo apresenta, dessa forma, elevados índices numa extensa faixa à Norte (IBGE, 2010), compreendendo as unidades residenciais 
localizadas entre os trilhos da viação férrea e a avenida João Machado Soares, onde se localizam o Loteamento Irmão Leão, a Vila Vitorio do Rossato, a Vila Jardim e o Loteamento Monfardini. Esse último, apresenta uma porcentagem entre 15\% e 18\% de pessoas analfabetas. Além das áreas sem denominação, localizadas à Norte da estrada de ferro, que também apresentam índice alto de analfabetismo, entre 11\% e 15\% de população nessa condição.

Além dessas unidades residências, fazem parte dessa área, também, três ocupações irregulares (Beco do Beijo, Vila Aparício de Moraes e Vila Jardim), conforme representado na figura 4. Em Santa Maria, as ocupações irregulares surgem, em velocidade maior do que a capacidade do poder público de regularizá-las, reafirmando um problema histórico com relação ao acesso à moradia na cidade.

As ocupações irregulares, por estarem fora da legislação urbana, não são comtempladas com os serviços de infraestrutura urbana considerados básicos, como saneamento ou a energia elétrica, por exemplo. Embora se trate de um Bairro universitário, o saneamento básico é um problema que se mostra em praticamente todas as suas áreas. Entretanto, são nessas áreas ocupadas que os problemas socioespaciais aparecem com mais intensidade.

Na Vila Aparício de Moraes e no Beco do Beijo, parte das habitações são inadequadas para a moradia, com ausência de saneamento básico e outros serviços, o que denota essas áreas como territórios de privação social em Camobi. Essas áreas de pobreza urbana apresentam um espaço cristalizado, onde o tempo e os homens são lentos (SANTOS, [1996] 2017)iii, pois o uso do território não se dá através da lógica mercantil, visto que não são atrativas para a produção de edifícios ou condomínios.

Por outro lado, a valorização da terra urbana nas áreas no entorno da Universidade, leva ao deslocamento da população de classe baixa para as áreas de periferia, em grande parte dos casos para ocupações irregulares. Portanto, trata-se de um uso seletivo do território, que revela a "Geografia da desigualdade" nos territórios, como bem afirmou Souza (1999).

Opostamente a essa realidade, nas proximidades da UFSM encontram-se 4 loteamentos horizontais em fase de construção, além de 1 condomínio residencial 
vertical em construção. Essas unidades residenciais ocupam grandes extensões de terra urbana, como por exemplo o Loteamento Verdes Pampas (ver mapa da figura 4), com área aproximada de 14 hectares, arruamento, sistema de água, esgoto e iluminação, atualmente em fase final de obras. Contudo, na COHAB Fernando Ferrari, área limítrofe com as unidades residenciais em construção, embora não haja ocupações irregulares no momento atual (ano de 2019), os problemas relacionados a infraestrutura urbana ainda são presentes, sobretudo no que se refere o saneamento básico.

Com relação a produção de edifícios, conforme mencionado anteriormente, no ano de 2017 somava-se o total de 49 prédios em construção no Bairro (SPODE, 2017), número que já se elevou consideravelmente, visto a rapidez com que o processo de verticalização se reproduz no território de Camobi. Ao contabilizarmos somente os prédios em construção do condomínio vertical "Morada do Leste", que prevê a produção de 23 edifícios de moradia, contabiliza-se o total de 72 edifícios em fase de construção no Bairro, um aumento de 68 \% em 2 anos.

Segundo reportagem veiculada no jornal Diário de Santa Maria (2019), o condomínio vertical "Morada do Leste", em fase inicial de construção na Avenida João Machado Soares, é um projeto com investimento de R\$122 milhões. A obra contará com 23 prédios de 8 andares cada, somando 736 unidades residenciais. Segundo nota do Diário de Santa Maria (2019), a empresa responsável pela obra irá pagar uma medida compensatória, prevista no Plano Diretor da cidade (SANTA MARIA, 2005), que será utilizada pelo poder público do município, para reforma de uma escola municipal, de um posto de saúde, manutenção de uma praça, reparação das paradas de ônibus precárias e construção de uma ciclovia.

Essas intervenções, cabe destacar, serão realizadas nas áreas ao entorno do empreendimento residencial, atribuindo valor a terra urbana naquela área, através do capital privado, além de revitalização do "Calçadão", no centro da cidade (DIÁRIO DE SANTA MARIA, 2019). Isto é, parte do investimento será utilizado em áreas distantes, no centro da cidade, caracterizando-se como decisões que são exógenas ao território 
de Camobi, sobretudo da população da região Norte do Bairro, principal afetada pelo empreendimento.

Embora a empresa esteja pagando uma medida compensatória prevista pela legislação da cidade, o poder público se exime do investimento em infraestrutura urbana, de certa maneira, transferindo para o privado, que usa o território da forma que será mais conveniente para seus interesses. Desse modo, os empreendimentos residenciais são reproduzidos no Bairro, reafirmando, cada vez mais, o uso imobiliário-coorporativo do território de Camobi, materializados em condomínios horizontais e edifícios verticais.

\section{CONSIDERAÇÕES FINAIS}

A configuração espacial de Camobi foi construída ao longo do tempo através da sobreposição e ressignificação dos seus usos. No primeiro momento, o uso do território a partir da estação ferroviária, concentrando as atividades no chamado Camobi antigo, Norte do Bairro, e no segundo momento, com os novos objetos implantados, principalmente a partir da instalação da UFSM e a BASM. Nesse sentido, quando o sistema ferroviário entra em decadência, uma nova dinâmica econômica emerge e produz o espaço, iniciando a urbanização efetiva do distrito, e mais tarde, levando-o à transformação em Bairro, na década de 1980.

Embora os processos socioespaciais já ocorressem no período histórico anterior, é com a Universidade Federal que a transformação espacial de Camobi passa a ocorrer de forma dinâmica, exercendo influência direta na urbanização do Bairro. Com isso, esses processos passam a se acentuar, sobretudo com a chegada da especulação imobiliária, que com seu modo coorporativo de uso do território, influencia diretamente a reprodução de problemas socioespaciais, como pobreza e a segregação residencial.

Nesse sentido, este trabalho buscou evidenciar como se configuram esses processos atualmente, partindo da noção dos usos historicamente produzidos no território de Camobi, através do princípio da seletividade espacial. É esse processo 
social espacialmente seletivo que produz uma distribuição desigual das infraestruturas e das possibilidades para a própria reprodução do capital. A presença de territórios de pobreza urbana e privação social é reflexo desse processo e devem ser adequadamente pensadas nos instrumentos de planejamento urbano, com especial atenção ao Plano Diretor de Desenvolvimento Territorial de Santa Maria.

\section{AGRADECIMENTOS}

O presente trabalho foi realizado com apoio da Coordenação de Aperfeiçoamento de Pessoal de Nível Superior - Brasil (CAPES) - Código de Financiamento 001.

\section{REFERÊNCIAS}

ALEXANDRIA CONDOMÍNIOS. Portfolio sobre o condomínio Alexandria. A filosofia. Disponível em: <http://www.condominioalexandria.com.br/> Acesso em 22 de fev de 2019.

BECKER, E. L. S. Mapeamento das classes de uso do solo urbano no setor norte do Bairro Camobi - Santa Maria - RS: 1966-1992. Trabalho de Graduação, Departamento de Geociências, Centro de Ciências Naturais e Exatas, Universidade Federal de Santa Maria, 1996.

COMIN, F. V. Dinâmica espacial e segregação residencial no Bairro Camobi-Santa Maria/RS. Dissertação de Mestrado. Programa de Pós-Graduação em Geografia Universidade Federal do Rio Grande do Sul, 2013.

COMIN, F. V. Estudo da Expansão Territorial Urbana e do Uso do Solo urbano nas três principais vias do Bairro Camobi - Santa Maria/RS. Trabalho de Graduação. Universidade Federal de Santa Maria/RS, 2008.

DEGRANDI, J. O. Verticalidades e horizontalidades nos usos do território de Santa Maria-RS. Tese de Doutorado, Santa Cruz do Sul. Universidade de Santa Cruz do Sul, 2012.

DIÁRIO DE SANTA MARIA. Construtora que fará condomínio em Camobi reformará escola, posto, parada e 0 Calçadão. Disponível em: https://diariosm.com.br/notícias/economia/construtora-que-fará-condomínio-em-camobireformará-escola-posto-parada-e-o-calçadão-1.2137365. Acesso em 14 de ago de 2019. 
FARIA, R. M. A territorialização da atenção primária à saúde no Sistema Único de Saúde: perspectiva de adequação aos perfis do território urbano de Pouso Alegre MG. Campinas, SP, 2012.

IBGE. Censo Demográfico de 2010: Resultados do Universo. Rio de Janeiro: Centro de Documentação e Disseminação de Informações, 2010.

IBGE. Estimativas Populacionais de 2017. Disponível em: https://cidades.ibge.gov.br/xtras/temas.php?codmun=0\&idtema=130. Acesso em 20 de nov de 2018.

KLARMANN, H. Diagnóstico e Prognóstico do Bairro Camobi - Santa Maria - RS. Departamento de Geociências. UFSM. 1990.

MINAYO, M. C. de S. O desafio do conhecimento: pesquisa qualitativa em saúde. 7. ed. São Paulo: Rio de Janeiro: Hucitec/Abrasco, 2000.

PRADO, T. C. S. Formas atuais de exclusão residencial no espaço urbano de Santa Maria - RS: uma análise dos condomínios horizontais fechados e das áreas ocupadas de forma irregular. 2010. 112f. Monografia - Universidade Federal de Santa Maria, 2010.

PRATES, L. O. Esgoto em Camobi: paralisação momentânea de obra foi discutida com a comunidade. Disponível em: https://www.santamaria.rs.gov.br/noticias/9136-esgotoem-camobi-paralisacao-momentanea-de-obra-foi-discutida-com-a-comunidade-nestasegunda. Acesso em: 20 de jun de 2018.

RIZZATTI, M. A Cartografia Escolar e as Inteligências Múltiplas no Ensino de Geografia: Contribuições das Geotecnologias no Ensino Fundamental. Dissertação - Universidade Federal de Santa Maria, Centro de Ciências Naturais e Exatas, Programa de Pós-Graduação em Geografia, RS, 2018.

RIZZATTI, M.; CASSOL, R.; BATISTA, N. L.; SPODE, P. L. C. A compreensão do espaço urbano pela distribuição das faixas etárias do Bairro Camobi, Santa Maria, RS. Anais [do] Simpósio Internacional do SELPER, Puerto Iguaçu, Argentina, 2017.

ROCHA, L. H. M. da, O papel de Santa Maria como centro de drenagem da renda fundiária. 1993. 179 p. Dissertação (Mestrado em Desenvolvimento Regional e Urbano) Universidade Federal de Santa Catarina, Santa Catarina, 1993.

ROCHA, L. H. M. da, Padrão locacional da estrutura social: segregação residencial em Santa Maria - RS. 2011. Tese (Doutorado), Santa Catarina. Universidade Federal de Santa Catarina, 2011.

SANTA MARIA, Lei Complementar $\mathbf{N}^{\circ}$ 034, de 29 de dezembro de 2005. Política de Desenvolvimento Urbano e sobre o Plano Diretor de Desenvolvimento Urbano Ambiental do Município de Santa Maria. Disponível em: 
<https://www.santamaria.rs.gov.br/docs/leis/lc_034_plano_diretor.pdf>. Acesso em 09 de set de 2019.

SANTA MARIA. Lei Complementar $\mathbf{N}^{\circ}$ 117, de 26 de junho de 2018. Institui a Lei de Uso e Ocupação do Solo, Parcelamento, Perímetro Urbano e Sistema Viário do Município de Santa Maria. Disponível em: < http://iplan.santamaria.rs.gov.br/uploads/norma/18078 /Lei_Complementar_117_2018_LUOS.pdf 2018. Acesso em 24 de nov de 2018.

SANTA MARIA. Lei Complementar No. 042/2006 de 29 de dezembro de 2006. Santa Maria: Câmara Municipal, 2006. Disponível em: http://www.camara-sm.rs.gov.br. Acesso em 10 abr de 2019.

SANTA MARIA. Lei Municipal de $\mathbf{N}^{\circ} . \mathbf{2 4 1 0 / 8 2}$ de 14 de outubro de 1982. Santa Maria: Câmara Municipal, 1982. Disponível em: http://www.camara-sm.rs.gov.br. Acesso em 10 de mar de 2018.

SANTA MARIA. Lei Municipal de $\mathbf{N}^{\mathbf{0} .2770 / 86}$ de 02 de julho de 1986. Santa Maria: Câmara Municipal, 1986. Disponível em: http://www.camara-sm.rs.gov.br. Acesso em 27 de abr de 2019.

SANTOS, M. A Natureza do Espaço. Técnica e tempo, razão e emoção. 4.ed. 9 reimp. São Paulo: Editora da Universidade de São Paulo. 2017.

SANTOS, M. A Natureza do Espaço. Técnica e tempo, razão e emoção. São Paulo. Hucitec. 1996.

SANTOS, M. A Urbanização Brasileira. São Paulo: Hucitec, 1993.

SANTOS, M. Metamorfoses do espaço habitado. São Paulo: Hucitec, v. 4, p. 136, 1988.

SANTOS, M. Por uma Geografia Nova. São Paulo: Hucitec, 1978.

SANTOS, M; SILVEIRA, M. L. O Brasil: território e sociedade no início do século XXI. Rio de Janeiro: Record. 2011.

SEN, A. Desenvolvimento como liberdade. Editora Companhia das Letras, 2018.

SOUZA, M. A. A. de. Território, soberania e mundo novo. Assembleia Legislativa do Estado de Minas Gerais. 1999.

SPIAZZI, C. F. T. Análise dos aspectos populacionais, infra-estrutura e equipamentos urbanos das Vilas Soares do Canto, Jardim e Aparício de Moraes no Bairro CamobiSanta Maria-RS. 2002. 67 f. Monografia (Bacharelado em Geografia), Curso de GeografiaUniversidade Federal de Santa Maria, Santa Maria, 2002.

SPODE, P. L. C. Verticalização e Produção do Espaço Urbano no Bairro Camobi, Santa Maria, RS, em 2017. Trabalho de Graduação - Universidade Federal de Santa Maria, 
Centro de Ciências Naturais e Exatas, Departamento de Geociências, Curso de Geografia Licenciatura Plena, RS, 2017.

SPODE, P. L. C.; ROCHA, L. H. M.; FARIA, R. M. Valorização e produção do espaço urbano no Bairro Camobi, Santa Maria, RS, em 2017: uma análise a partir do mercado de imóveis verticais. Anais do XIV Seminário Internacional de Estudos Urbanos e Regionais e III Colóquio sobre Cidade e Cidadania. Pelotas, RS, Brasil, 2018.

\footnotetext{
' Na definição em relação à rede de cidades do Rio Grande do Sul (FARIA et al., 2019).

ii A matéria foi publicada em outubro do ano de 2014 e pode ser encontrada no website a seguir:

https://www.santamaria.rs.gov.br/noticias/9136-esgoto-em-camobi-paralisacao-momentanea-deobra-foi-discutida-com-a-comunidade-nesta-segunda.

iii Milton Santos chama de "homens lentos" as camadas mais pobres da sociedade, que ao contrário dos espaços hegemônicos, que são velozes, estes observam o mundo através da realidade social dos "hegemonizados", dos privados, ou seja, os pobres da cidade. No entanto, como profetizou o autor em A Natureza do Espaço, o tempo das cidades, hoje, é o tempo dos homens lentos. "A força é dos "lentos" e não dos que detém a velocidade", relata o autor, e complementa: "É assim que eles escapam ao totalitarismo da racionalidade, aventura vedada aos ricos e às classes medias. Desse modo, acusados por uma literatura sociológica repetitiva, de orientação ao presente e de incapacidade de prospectiva, são os pobres que, na cidade, mais fixamente olham para o futuro" (SANTOS, 2017, p. 325).
} 